\title{
FATORES CRÍTICOS ADVINDOS DO EMPREGO DE BOMBEIROS VOLUNTÁRIOS E CIVIS NA PROTEÇÃO E DEFESA CIVIL NO ESTADO DA BAHIA
}

\author{
Ednei da Silva Factum dos Anjos ${ }^{1}$ \\ Eloi Camacho Garcia ${ }^{2}$ \\ Ricardo Bernardes Frank ${ }^{3}$
}

\section{RESUMO}

A multiplicidade de ocorrências e o enorme território do Estado da Bahia impõem ao Corpo de Bombeiros Militar da Bahia ações estratégicas para melhor lidar com bombeiros civis e voluntários de forma a buscar trazê-los para categoria de forças amigas no enfrentamento das demandas de defesa civil e, também, das cotidianas de menor complexidade. A realidade exige atenção impar do escalão superior da Corporação a fim de preservar a identidade e a imprescindibilidade do CBMBA, sem descurar de importante força de trabalho especializado, sobretudo no interior do Estado, ante os 417 municípios, em sua grande maioria, carentes do serviço bombeiro-militar, sobretudo, quando se trata de desastres de grandes proporções. Desta forma, registram-se, conceitualmente, as diferenças entre bombeiro militar, bombeiro civil e bombeiro voluntário, fixando atribuições, limites de atuação e regime jurídico, informando as potencialidades de cada um desses atores e propondo alternativas de enfrentamento político, social e jurídico de possíveis ameaças ao papel institucional do Corpo de Bombeiros Militar.

Palavras-chave: Defesa civil. Bombeiro militar. Bombeiro civil. Bombeiro voluntário. Distinções.

\footnotetext{
1 Especialista em Segurança Pública (UNEB), Segurança contra Incêndio e Resgate (UNIFACS), Direitos Humanos e Cidadania (UNEB), Bacharel em Segurança Pública e Administração (UNEB), Bacharel em Direito (UFBA) e Tenente-coronel do Corpo de Bombeiros Militar da Bahia. ednei.factum@cbm.ba.gov.br

${ }^{2}$ Especialista em Segurança Pública (UNEB), Bacharel em Segurança Pública e Administração (UNEB), Bacharel em Direito (UNIME) e Tenente-coronel do Corpo de Bombeiros Militar da Bahia.Eloi.camacho@cbm.ba.gov.br

${ }^{3}$ Especialista em Segurança Pública (UNEB), Bacharel em Segurança Pública e Administração (UNEB), Bacharel em Direito (UCSAL) e Tenente-coronel do Corpo de Bombeiros Militar da Bahia.rb.frank@yahoo.com.br
} 


\title{
CRITICAL FACTORS ARISING FROM YHE EMPLOYMENT OF VOLUNTEER AND CIVIL FIREFIGHTERS IN CIVIL PROTECTION AND DEFENSE IN THE STATE OF BAHIA
}

\begin{abstract}
The multiplicity of occurrences and the huge territory of the State of Bahia impose on the Corpo de Bombeiros Militar da Bahia strategic actions to better deal with civilian and volunteer firefighters in order to seek to bring them into the category of friendly forces in facing the demands of civil defense and, also, of less complex daily life. The reality demands unparalleled attention from the top echelon of the Corporation in order to preserve the identity and indispensability of CBMBA, without neglecting an important specialized workforce, especially in the interior of the state, in front of the 417 municipalities, most of whom lack the service military-firefighter, especially when it comes to major disasters. In this way, the differences between the military firefighter, civil firefighter and voluntary firefighter are conceptually registered, establishing attributions, limits of performance and legal regime, informing the potential of each of these actors and proposing alternatives for political, social and legal coping. possible threats to the institutional role of the Military Fire Brigade.
\end{abstract}

Keywords: Civil Defense. Military Firefighter. Civil Firefighter. Voluntary Firefighter. Distinctions. 


\section{INTRODUÇÃO}

O corpo de bombeiros teve origem, no Brasil, com o Imperador Dom Pedro II, em 2 de julho de 1856, mediante o Decreto Imperial no 1.775, com a criação do Corpo de Bombeiros Provisório da Corte, cuja responsabilidade territorial restringia-se à cidade do Rio de Janeiro. O dia de criação, atualmente, inaugurou data comemorativa do Dia Nacional do Bombeiro e da Semana de Prevenção Contra Incêndios. Assim, no início, o corpo de bombeiros não teve natureza militar, ficando a cargo das províncias e, posteriormente, dos principais municípios, notadamente, as capitais de Estado. Depois, passou a integrar as forças policiais dos respectivos Estados da Federação, as quais possuíam caráter estadual e militar, enquanto forças auxiliares e reservas do Exército brasileiro.

De sua criação aos dias atuais, os corpos de bombeiros passaram por inúmeras transformações. Alguns já nasceram estaduais e independentes da Polícia Militar de seu Estado, como ocorreu com o Corpo de Bombeiros do Estado do Rio de Janeiro. Outros derivaram das antigas províncias imperiais, inserindo-se, com a proclamação da República, no orgânico das instituições municipais e, a partir daí, nas respectivas forças policiais.

$\mathrm{Na}$ Bahia, o corpo de bombeiros seguiu esse longo percurso, desde o Corpo de Bombeiros da Cidade do Salvador, criado pelo prefeito municipal Conselheiro José Luiz de Almeida Couto, mediante a Lei ㄲo 124, de 26 de dezembro de 1894. Com o advento da Lei estadual ํㅡ 4.075, de 8 de novembro de 1982, foi criado o Comando do Corpo de Bombeiros, na estrutura da Polícia Militar da Bahia, absorvendo a antiga instituição municipal à chamada Milícia de Bravos, cuja implementação somente se deu dois anos mais tarde.

Em 30 de junho de 2014, mediante a Emenda Constitucional $n^{\circ} 20$, o Corpo de Bombeiros Militar da Bahia ganhou autonomia administrativa e financeira, passando a constituir corporação militar estadual independente. 
Com dotação orçamentária e estrutura administrava próprias, o CBMBA ganhou em tecnologia, efetivo e constante treinamento, crescendo em mais cinco unidades operacionais, das quais quatro já estão devidamente implantadas e a $20^{\mathrm{a}}$, já em vias de inauguração.

Novos desafios apresentaram-se com o crescimento. As cidades verticalizaram-se e as demandas do interior multiplicaram-se pelo natural crescimento econômico da região, obrigando a corporação a manter contínuo processo de capilarização mediante instalação estratégica de subgrupamentos de bombeiros militares em constante processo de interiorização.

$O$ investimento em material e pessoal requer grandes somas do poder público, impondo parcerias e convênios, quer com a iniciativa privada quer com os demais entes estatais. Nesse sentido, o bombeiro civil e o bombeiro voluntário, não raro, são apresentados como possíveis alternativas de redução de custos frente às múltiplas demandas de defesa civil e de mero cumprimento das missões rotineiras de combate a incêndio e de salvamento. $O$ que, por via de consequência, se não observados determinados requisitos, poderão constituir ameaça à instituição bombeiro-militar tal qual a conhecemos na atualidade.

O conjunto de atributos de um bombeiro militar impõe tempo e formação específicos, uniformes, viaturas, equipamentos e instalações físicas (quartéis) notadamente mais caros, inclusive, no montante destinado aos soldos, que o valor necessário à criação de um posto de bombeiro civil ou de bombeiro voluntário. Assim, uma análise superficial, detida unicamente no custo, pode levar o gestor público maior à, de maneira desavisada, implementar medidas tendentes ao esvaziamento do bombeiro militar.

Nesse sentido, quando dos primeiros anos de criação do CBMBA, em busca de notoriedade e espaço, inúmeras ocorrências envolvendo bombeiros civis e voluntários, muita vez em superposição à missão constitucional do CBMBA, clamou pela atenção do escalão superior, o que resultou em diversos 
estudos técnicos a respeito do tema, a fim de esclarecer os limites legais de atuação desses profissionais.

A maior parte desses estudos concluíam pela total restrição e completo afastamento do setor, obviamente pelo receio, à época, justificado pelas constantes ocorrências que denotavam usurpação de função pública e uso indevido de imagem. O termo bombeiro civil ou bombeiro voluntário passou, então, a representar espécie de persona non grata nos quartéis do CBMBA. Assim, antigas parcerias de treinamento, discussão de temas técnicos e, até mesmo, de enfrentamento e combate, foram deixadas de lado, cedendo lugar a uma tentativa de encapsulamento, cuja fragilidade fora testada no primeiro grande incêndio florestal na Chapada Diamantina, no ano de 2015, fazendo repensar o modelo informalmente proposto. As brigadas locais perfilaram esforços ao CBMBA e fizeram frente a meses de combate a um dos maiores incêndios florestais da história da região. Durante o episódio, a separação era nítida, com bombeiros militares combatendo durante o dia, e brigadistas, em jornadas noturnas.

Desse momento, implementaram-se importantes parcerias entre o poder público, as lideranças locais, entidades não governamentais e alguns entes privados, como pousadas e hotéis, na formação, treinamento e implementação de brigadas de prevenção e combate a incêndio florestal, a fim de tentar cobrir parte da infinidade de terras dos diversos parques e áreas de proteção ambiental da região. Tal atuação do CBMBA passou a constituir peça importante do programa do governo estadual intitulado Bahia sem Fogo, da Secretaria do Meio Ambiente - SEMA.

A proteção e defesa civil impõem, exatamente pela abrangência de suas ações e dimensão dos esforços de prevenção, mitigação, preparação, resposta e recuperação, a formação de um sistema envolvendo diversos órgãos, entidades e sociedade civil, nas três esferas de poder, municipal, estadual e federal. Daí a importância solar de somar aos bombeiros militares novas forças amigas, especialmente, aquelas (bombeiros civis e bombeiros voluntários) com 
nítido potencial de ombrear esforços no momento, possivelmente, mais crítico de qualquer desastre ou ocorrência, a resposta (BRASIL, 2012). 


\section{ATUAÇÃO DO BOMBEIRO MILITAR E DO BOMBEIRO CIVIL}

Inicialmente, faz-se importante distinguir, de forma conceitual, bombeiro militar, bombeiro civil e bombeiro voluntário. O bombeiro militar, nos termos do art. 46, da Constituição baiana, é o servidor militar estadual integrante do Corpo de Bombeiros Militar da Bahia (CBMBA), cuja disciplina será estabelecida em estatuto próprio ${ }^{4}$. O bombeiro civil é a pessoa que, nos termos da Lei federal $n^{\circ} 11.901$, de 12 de janeiro de 2009, exerce, em caráter habitual, função remunerada e exclusiva de prevenção e combate a incêndio, como empregado contratado diretamente por empresas privadas ou públicas, sociedades de economia mista, ou empresas especializadas em prestação de serviços de prevenção e combate a incêndio. $O$ bombeiro voluntário, por sua vez, é uma figura tratada pelo constituinte derivado, a partir da Emenda Constitucional baiana $n^{\circ} 20$, de 30 de junho de 2014. O texto constitucional baiano não contempla definição de bombeiro voluntário, cabendo, portanto, à doutrina e à jurisprudência tal mister.

É de se notar que, no âmbito laboral, o bombeiro civil não integra, necessariamente, instituição que o defina. Vale dizer, qualquer pessoa que, habitualmente, exerça função remunerada e exclusiva de prevenção e combate a incêndio, como empregado, será considerado bombeiro civil, desde que, obtenha prévia aprovação em curso preparatório ou de formação, ministrado por instituição ou empresa especializada em prevenção e combate a incêndio, mediante níveis de graduação técnica e funcional da profissão ${ }^{5}$. Isto porque o

\footnotetext{
${ }^{4} \mathrm{O}$ art. 68, da Lei n. ${ }^{\circ} 13.202$, de 9 de dezembro de 2014, determina a aplicação da Lei $n .{ }^{\circ}$ 7.990, de 27 de dezembro de 2001, Estatuto dos Policiais Militares.

${ }^{5} \mathrm{O}$ art. 4을 da Lei n. ${ }^{\circ} 11.901$, de 12 de janeiro de 2009, estabelece que as funções de Bombeiro Civil são classificadas em: I - Bombeiro Civil, nível básico, combatente direto ou não do fogo; II - Bombeiro Civil Líder, o formado como técnico em prevenção e combate a incêndio, em nível de ensino médio, comandante de guarnição em seu horário de trabalho; III - Bombeiro Civil Mestre, o formado em engenharia com especialização em prevenção e combate a incêndio, responsável pelo Departamento de Prevenção e Combate a Incêndio. A IT n. ${ }^{\circ}$ 17/CBMBA, por sua vez, assim define: Brigadista Nível I: pessoa, voluntária ou não, empregada em caráter não exclusivo como componente da brigada de incêndio, treinada e capacitada em prevenção
} 
bombeiro civil tem esfera de atuação limitada espacialmente e em conteúdo, como veremos adiante, sendo o empregador o responsável direto por sua atuação. Vejamos entendimento do Tribunal Regional do Trabalho, da $18^{\underline{a}}$ Região, do Estado de Goiás:

\begin{abstract}
BOMBEIRO CIVIL. ENQUADRAMENTO NA LEI N. ${ }^{\circ}$ 11.901/2009. HABILITAÇÃO DESNECESSÁRIA

O empregado que, comprovadamente, desempenha atividade diretamente ligada à prevenção e combate a incêndio, mesmo quando não qualificado pelo empregador como bombeiro, e ainda que fique à disposição da empresa para eventual exercício deste mister, enquadra-se na definição de bombeiro civil, prevista no art. $2^{\circ}$, da Lei $n^{\circ} 11.901 / 09$, que, por sua vez, não exige habilitação especial, aos que exercem função exclusiva de prevenção e combate (direto ou não) ao fogo (art. 4으, I, da Lei $n^{\circ}$ 11.901/09), sendo-lhes devidos todos os direitos previstos na referida lei especial, tais como jornada de trabalho reduzida de 36 horas semanais e adicional de periculosidade (Grifo nosso).
\end{abstract}

Note-se que o bombeiro civil é, portanto, empregado contratado por pessoa jurídica pública ou privada, regido pela Consolidação das Leis do Trabalho e pela Lei $n^{0} 11.901$, de 12 de janeiro de 2009, e, desta forma, sujeito a remuneração pela força de trabalho despendida, independentemente de habilitação prévia em curso de formação e ou treinamento habitual.

O bombeiro voluntário, por outro lado, nos termos do texto constitucional baiano, exige instrução e orientação do CBMBA. Vale dizer, a mera prática

e combate a incêndios, primeiros socorros e abandono de áreas, em edificações, estruturas ou áreas de risco, que tenha formação de acordo com o Anexo B. Brigadista Nível II: pessoa, voluntária ou não, empregada em caráter exclusivo ou não, como componente da brigada de incêndio, treinada e capacitada em prevenção e combate a incêndios, primeiros socorros e abandono de áreas, em edificações, estruturas ou áreas de risco, que tenha formação de acordo com o Anexo B. Bombeiro Civil: pessoa habilitada, com formação em Bombeiro Profissional Civil conforme NBR 14.608, componente da brigada de incêndio, que exerce, em caráter habitual, função remunerada e exclusiva de prevenção e combate a incêndios e primeiros socorros, contratada diretamente por empresas privadas ou públicas, por sociedades de economia mista ou por empresas especializadas, para atuação em edificações, estruturas e áreas de risco. Chefe de Brigada: Responsável por coordenar, orientar e atuar nas ações de emergência na edificação onde a Brigada de incêndio atue, além de auxiliar o supervisor nas ações de prevenção contra incêndio e pânico. Monitor: pessoa com conhecimento técnico, teórico e prático em primeiros socorros e/ou combate a incêndio e com experiência compatível com o nível de treinamento (BAHIA, 2016). 
reiterada ou habitual da atividade de prevenção e combate a incêndio não habilita o indivíduo à categoria de bombeiro voluntário. É imprescindível, portanto, nos limites territoriais do Estado da Bahia, a instrução e a orientação do Corpo de Bombeiros Militar para que alguém seja considerado bombeiro voluntário. Demais disso, para a qualificação de voluntário exige-se que o serviço prestado se dê sem fins lucrativos, ou seja, sem qualquer remuneração ou contraprestação pelo desforço físico e mental despendido pelo voluntário. Vejamos extensão do verbete de dicionário para o termo voluntariado:

\section{Voluntariado:}

Ideia relacionada à busca de conscientização das pessoas, de mobilização de grupos sociais marginalizados na defesa dos seus direitos, de influência de políticas públicas e outras ações no campo da cidadania.

O conceito atual de voluntariado tem origem nos anos 80 , com a militância das organizações não-governamentais (ONGs) em defesa da causa ambiental. Depois, conquistaram maior atenção as questões de gênero, o direito do consumidor, do idoso e do portador de deficiência, constituindo uma crescente especialização em termos de área de atuação e público-alvo. $\mathrm{Na}$ década de 90, no âmbito das empresas, floresceram os conceitos de cidadania empresarial e responsabilidade social empresarial, visando promover o desenvolvimento social a partir do incentivo a projetos auto-sustentáveis, em oposição às tradicionais práticas de caráter paternalista, do assistencialismo gerador de dependência e mantenedor da ordem vigente.

Nos anos 90, também surge o conceito de terceiro setor, conjunto de organizações da sociedade civil de direito privado, sem fins lucrativos e voltadas para fins públicos, incluindo ONGs, organizações comunitárias, braços sociais de empresas como institutos e fundações e outras instituições que nascem na sociedade civil com a finalidade de desenvolver atividades em prol do bem comum. Dessa forma, o voluntariado foi se constituindo como um fenômeno global, sendo entendido como um componente essencial de sociedades democráticas e participativas.

No Brasil, em fevereiro de 1998, o governo brasileiro criou a Lei n.ำ 9.608, conhecida como Lei do Serviço Voluntário. De acordo com a lei, considera-se serviço voluntário a atividade não remunerada, prestada por pessoa física a entidade pública de qualquer natureza ou instituição privada de fins não lucrativos, que tenha objetivos cívicos, culturais, 
educacionais, científicos, recreativos ou de assistência social, inclusive mutualidade. A Lei do Serviço Voluntário, pretendendo incentivar as empresas a implementar programas de voluntariado, classificou o serviço voluntário como atividade não-remunerada, que não gera vínculo empregatício nem obrigação de natureza trabalhista, previdenciária ou afim.

O Conselho da Comunidade Solidária é uma das organizações que contribuiu, a partir de 1995, para fomentar a cultura do voluntariado no Brasil, através do lançamento de diversos programas. No âmbito da educação básica, o Comunidade Solidária promove o Programa Alfabetização Solidária, que visa o combate ao analfabetismo no Brasil. (MENEZES, 2002 - Grifo nosso).

Conceituados bombeiro militar, bombeiro civil e bombeiro voluntário, passemos às considerações acerca da limitação legal da atividade de cada um desses personagens e suas implicações. O primeiro, nos termos do art. 148-A, da Constituição do Estado da Bahia, é integrante do Corpo de Bombeiros Militar da Bahia, força auxiliar e reserva do Exército, organizado com base na hierarquia e disciplina. O CBMBA é órgão integrante do sistema de segurança pública, ao qual compete as atividades de defesa civil; prevenção e combate a incêndios e a situações de pânico; busca, resgate e salvamento de pessoas e bens; instrução e orientação de bombeiros voluntários, onde houver; e polícia judiciária militar, a ser exercida em relação a seus integrantes, na forma da lei federal (código penal e processual penal militar).

\section{O CORPO DE BOMBEIROS MILITAR DA BAHIA E O BOMBEIRO VOLUNTÁRIO}

De notar, portanto, que ao bombeiro militar baiano cabe a prestação de serviço público de forma ampla e irrestrita no território do Estado da Bahia. Vale dizer, em áreas públicas ou privadas, o bombeiro militar tem competência legal para atuar nas mais variadas ocorrências, sempre na defesa e preservação da vida e do patrimônio, sendo imprescindível à qualidade de seus serviços o constante treinamento e a regular qualificação tecnológica de seus equipamentos. 
Já o bombeiro civil, sua competência sofre limitação espacial e de conteúdo. Da simples leitura do caput do art. $2^{\circ}$, segunda parte, da Lei $\mathrm{n}^{\circ}$ 11.901/09, vê-se que o vínculo empregatício do bombeiro civil se dá com empresas privadas ou públicas, sociedade de economia mista ou empresas especializadas na prestação do serviço de prevenção e combate a incêndio, nunca com entes ou órgãos da Administração Direta (Poderes Executivo, Legislativo e Judiciário), em nenhuma das esferas federativas (federal, estadual e municipal), e jamais para prestação de serviço público da competência do Corpo de Bombeiros Militar, mesmo que sem remuneração direta. Vale dizer, não haverá o cargo público de bombeiro civil.

A Administração Direta faz frente à prevenção e ao combate inicial de incêndios por meio de suas brigadas de incêndio, normalmente compostas por servidores públicos integrantes do respectivo órgão, treinados para, cumulativamente com suas funções, atuar em situações emergenciais ou educativas, podendo valer-se, também, da terceirização de mão de obra mediante a contratação de empresa especializada na prestação de serviços de prevenção e combate a incêndios (última parte, do dispositivo legal anunciado).

Ora, se o liame laboral do bombeiro civil ocorre sob a modalidade de empregado contratado, tendo por empregador as entidades listadas acima, nitidamente a força de trabalho, objeto de tal vínculo laboral, dar-se-á no âmbito das instalações físicas do contratante, jamais em via pública, nunca sob a forma de serviço público, e se restringe, apenas e tão-somente, à prevenção e ao combate a incêndio, sendo vedado legalmente estender-se pelas demais atribuições do Corpo de Bombeiros Militar. Vejamos a definição legal de bombeiro civil na da Lei $n^{\circ} 11.901$, de 12 de janeiro de 2009:

Art. $2^{\circ}$. Considera-se Bombeiro Civil aquele que, habilitado nos termos desta Lei, exerça, em caráter habitual, função remunerada e exclusiva de prevenção e combate a incêndio, como empregado contratado diretamente por empresas privadas ou públicas, sociedades de economia mista, ou empresas especializadas em prestação de serviços de prevenção e combate a incêndio. (Grifo nosso). 
Nítido, portanto, que o bombeiro civil não poderá ser contratado para realizar, por exemplo, atendimento pré-hospitalar com vistas ao público de determinado evento em recinto fechado e, muito menos, em via pública.

A competência do CBMBA de credenciar bombeiros civis, elencada no art. $2^{\circ}, \mathrm{X}$, da Lei $n^{\circ} 13.202$, de 9 de dezembro de 2014, não possui natureza cogente, servindo apenas de referência positiva à empresa de bombeiro civil que assim proceda. O não-credenciamento, portanto, não implica penalidade, restrição ou qualquer outra forma de limitação de sua atuação, vez que a atividade de bombeiro civil regula-se pela Lei federal $n^{0}$ 11.901/2009, sujeitando-se somente às penalidades aí impostas.

Em igual medida, o cadastramento de empresas e profissionais habilitados a projetar e executar medidas de segurança contra incêndio e pânico, previsto no Decreto $n^{0}$ 16.302, de 27 de agosto de 2015, também não se mostra impositivo, de forma a que possibilite ao CBMBA aplicação de sanção administrativa que importe no impedimento da atuação profissional do não-cadastrado. Por óbvio que tal cadastramento serve de parâmetro oficial ao público em geral e, principalmente, ao potencial consumidor de tais serviços.

Diz-se, assim, que o legislador estadual está impedido de editar norma legal vedando o exercício de atividade profissional e tal impedimento decorre do mandamento constitucional de que legislar sobre direito do trabalho e condições para o exercício de profissões trata-se de competência privativa da União (incisos I e XVI, do art. 22, Constituição da República de 1988), matérias, portanto, somente tratadas por meio de lei federal. Lei complementar federal, no entanto, poderá autorizar os Estados a legislar sobre questões específicas de tais matérias (Parágrafo Único, art. 22, Constituição da República de 1988), a qual não fora, ainda, editada pela União.

O bombeiro voluntário, por outro lado, não sofrerá nem limitação de espaço nem de conteúdo. Deverá, no entanto, atuar somente sob instrução e orientação do CBMBA. Note-se que o constituinte baiano não restringiu a 
atuação do bombeiro voluntário a áreas internas ou privadas. Também não limitou sua atuação à prevenção e ao combate a incêndio. Exatamente por tudo isso, deixou claro que a existência de bombeiro voluntário pressupõe que o Corpo de Bombeiros Militar já se encontre devidamente instalado em tal localidade e com a especial atribuição de o instruir e o orientar antes e, principalmente, durante as ocorrências.

Instruir é o mesmo que transmitir conhecimentos, adestrar, ensinar como proceder, enquanto que orientar significa indicar a direção a ser seguida, dirigir, guiar, encaminhar, nortear. Logo, a ideia de orientação impõe constante e ininterrupto acompanhamento daquele a quem se orienta. Vejamos o que diz a Constituição da Bahia (1989):

Art. 148-A. O Corpo de Bombeiros Militar da Bahia, força auxiliar e reserva do Exército, organizado com base na hierarquia e disciplina, é órgão integrante do sistema de segurança pública, ao qual compete as seguintes atividades:

I - defesa civil;

II - prevenção e combate a incêndios e a situações de pânico;

III - busca, resgate e salvamento de pessoas e bens a cargo do Corpo de Bombeiros Militar;

IV - instrução e orientação de bombeiros voluntários, onde houver;

V - polícia judiciária militar, a ser exercida em relação a seus integrantes, na forma da lei federal. (Grifo nosso).

Ora, se compete ao Corpo de Bombeiros Militar a instrução e a orientação nas localidades, onde houver bombeiros voluntários, é porque, ali, já há unidade operacional do CBMBA. A contrario sensu, pode-se inferir que, no local onde não houver unidade do Corpo de Bombeiros Militar ${ }^{6}$, não deverá instalar-se bombeiro voluntário, porquanto, não só inexistirá quem o instrua e o oriente, mas também a quem prestar sua voluntariedade, posto que tal cooperação se dá para o Corpo de Bombeiros Militar (Lei n. 9.608/98), e não diretamente ao público, sob pena de usurpação de função pública (art. 328,

\footnotetext{
${ }^{6}$ A Lei $n^{\circ} 11.631$, de 30 de dezembro de 2009, em seu art. 1ํㅗ $\S 2^{\circ}$, traz ideia de limitação espacial da potencialidade do serviço de extinção de incêndios em razão da distância de 35 $\mathrm{Km}$ de unidade operacional do Corpo de Bombeiros Militar.
} 
do Código Penal brasileiro). Senão vejamos o que enuncia 0 art. $1^{\circ}$, da chamada Lei do Voluntariado:

Art. 1․ Considera-se serviço voluntário, para fins desta lei, a atividade não-remunerada, prestada por pessoa física a entidade pública de qualquer natureza, ou a instituição privada de fins não lucrativos que tenha objetivos cívicos, culturais, educacionais, científicos, recreativos ou de assistência social, inclusive mutualidade. (Grifo nosso)

Note-se que não se deve criar um ente e intitulá-lo de serviço voluntário. Trata-se de pessoas físicas que prestam serviço voluntário a um ente público ou a uma instituição privada sem fins lucrativos. É a hipótese, por exemplo, de se trabalhar voluntariamente em um hospital público ou privado. O serviço voluntário não cria o hospital, ele é a atividade desempenhada pelas pessoas físicas em apoio ou auxílio ao hospital público ou privado. Logo, a criação de entidades de bombeiro voluntário como um simulacro do Corpo de Bombeiros Militar, inclusive com fardamento, viaturas e edificações semelhantes aos quartéis, não se conforma à Lei de Serviço Voluntário, pelo contrário, caracteriza nítida usurpação de função pública (art. 328, do Código Penal brasileiro).

No âmbito do Estado da Bahia, os bombeiros voluntários, por força do art. 148-A, IV, são pessoas físicas que prestam serviço ao CBMBA, quer diretamente quer por meio de instituição privada sem fins lucrativos, a qual, como visto acima, não se constitui em entidade de bombeiro voluntário, posto que o bombeiro voluntário será sempre uma pessoa física, jamais jurídica.

Nesse sentido, a Lei $n^{\circ} 13.202$, de 9 de dezembro de 2014, no art. 2으, XIV, impõe ao bombeiro voluntário o seu cadastramento e habilitação no CBMBA. É de se observar que o termo habilitação implica requisito indispensável à prática de certa atividade, porquanto o não-habilitado está impedido de atuar. Diferentemente do que ocorre com o bombeiro civil, em que o credenciamento implica espécie de referência ou recomendação, sem o condão de impedir o bombeiro civil não-credenciado de exercer o seu mister. 
Tratando-se de atuação em conjunto, $\mathrm{o}$ atendimento a sinistros por bombeiros civis e/ou voluntários e bombeiros militares, a coordenação e a direção das ações caberão, com exclusividade e em qualquer hipótese, ao militar estadual $\left(\S 2^{\circ}\right.$, art. $2^{\circ}$, da Lei $n^{\circ} 11.901$, de 12 de janeiro de 2009 , c/c II, art. 148-A, da Constituição do Estado da Bahia). Daí inferirmos que o bombeiro voluntário sempre deverá atuar adstrito ao bombeiro militar, e o bombeiro civil, apenas quando a ocorrência privada ${ }^{7}$ demandar esforço paralelo do Corpo de Bombeiros Militar.

Importante ressaltar que o uso indevido de uniforme e/ou viaturas militares, ainda que semelhante, poderá constituir contravenção penal (art. 46, da Lei de Contravenções Penais), ou crime comum, caso implique utilização indevida de marca ou patente, como ocorre com apresentação de logomarcas em prédios ou outdoors à semelhança de quartéis militares, sujeitando os responsáveis às penas cominadas para o crime previsto no art. 191, da Lei $n^{\circ} 9.279$, de 14 de maio de 1996. Tratando-se de bombeiro civil, também poderá ensejar as penalidades impostas no art. $8^{\circ}$, da Lei $n^{\circ}$ 11.901/2009. Não há que se falar em crime militar, previsto no art. 172, do Código Penal Militar, ante a incompetência jurisdicional da Auditoria da Justiça Militar Estadual (AJME) para processar e julgar autor civil (§ 4º , do art. 125, da $\mathrm{CR} / 88$ ).

Na prática, o que se tem notícia, inclusive pelos meios de comunicação de massa escritos e televisivos, é que bombeiros civis, muita vez travestidos de voluntários, substituem-se ao Corpo de Bombeiros Militar no atendimento das mais diversas ocorrências em via pública, valendo-se da similitude das fardas e dos veículos que utilizam uniforme e viaturas paramilitares, para angariar adicional financeiro por meio da promoção ou reforço de sua imagem empresarial ao se passar por bombeiro militar. Nitidamente, subsumindo tal

\footnotetext{
${ }^{7}$ Por ocorrência privada entende-se o incêndio no interior ou na circunvizinhança do prédio em que o bombeiro civil presta os seus serviços.
} 
conduta ao quanto previsto no art. 191 , da Lei $n^{0} 9.279$, de 14 de maio de 1996.

Desta forma, pode-se vislumbrar inúmeras ocorrências com atuação simultânea desses três sujeitos, bombeiro militar, bombeiro civil e bombeiro voluntário. É ambiente que, por tudo que já foi dito, sugere significativo esforço de planejamento e coordenação, mas que, ante a enorme extensão territorial baiana, faz-se inevitável quando se trata de grandes desastres urbanos e ou ambientais.

Exemplo recente de evento que demandou enorme esforço do CBMBA e o consequente emparelhamento de esforços com bombeiros civis, mantidos por ONGs, entidades privadas e pelo poder público, foi o registrado na Chapada Diamantina, no ano de 2015. Tratou-se de incêndio florestal que se alastrou por mais de 40 localidades na região e que mobilizou cerca de 830 bombeiros militares por, pelo menos, quatro meses, incluindo apoio aéreo e emprego de militares do Corpo de Bombeiros Militar do Distrito Federal (BAHIA, 2015).

A rusticidade do terreno, acentuados acidentes naturais, clima quente e seco, distância entre os inúmeros focos e os mananciais, deram o tom da dificuldade de atuação do bombeiro militar baiano que, muita vez, estava familiarizado, unicamente, ao combate urbano. Assim, logo nos momentos iniciais do fogo, reconheceu-se impossível e pouco inteligente afastar importante força de trabalho representada por centenas de brigadistas que, além do nato conhecimento do terreno, possuíam a rusticidade e a experiência adequadas ao combate noturno.

As tarefas foram, assim, divididas. Bombeiros militares, durante o dia, e brigadistas, à noite. Minimizaram-se as divergências pelo afastamento temporal e o calor do longo combate tratou de aproximar e estreitar laços fraternos entre eles. Ao final, militares e civis comemoraram a extinção de um dos maiores incêndios na Chapada Diamantina e inauguraram projetos e programas 
públicos que passaram a contar institucionalmente com bombeiros civis como força amiga em ações de prevenção e combate a incêndio florestal.

O Programa Bahia sem Fogo, da Secretaria Estadual do Meio Ambiente, a partir de então, passou a organizar e empregar bombeiros militares na instrução e formação de brigadas de incêndio em localidades estratégicas do Estado, fornecendo recursos para pagamento de diárias aos instrutores e equipamentos de proteção individual e de combate para os instruendos, os quais já serviriam para os futuros combates. Desta forma, com a ação de brigadistas, treinados pelo CBMBA, garante-se o primeiro combate aos focos de incêndio, especialmente, nos períodos de maior estiagem, evitando o alastramento e o descontrole do fogo vivido no ano de 2015 (BAHIA, 2016).

Enormes somas em recursos públicos têm sido poupadas e o CBMBA saiu fortalecido desse episódio, inaugurando curso de capacitação especifica para seus militares, na área de combate a incêndio florestal, interiorizando e capilarizando este serviço.

Destarte, se foi possível ao CBMBA atuar com bombeiros civis e voluntários no combate a incêndio florestal, razão não há para se duvidar da possibilidade que tal parceria se estabeleça em outras searas, como enchentes, alagamentos, deslizamentos de terra e tantos outros desastres que, infelizmente, submetem a sociedade às forças da natureza e às ações desequilibradas do homem, demandando grandes esforços do poder público e enormes somas em dinheiro no restabelecimento social e econômico das áreas atingidas.

Demais disso, pela própria definição legal de bombeiro civil, razão não há para se prescindir de sua importância na prevenção e no combate inicial de focos de incêndio nos diversos tipos de edificações, sobretudo naquelas que guardam significativo público. De certo que o bombeiro militar, por mais aparelhado e bem distribuído que venha a estar, capilarizando seus serviços, jamais poderá fazer frente a todo território baiano. O bombeiro civil e, também, o bombeiro voluntário pode e deve ser alçado à categoria de força amiga, não 
apenas em ocorrências que impliquem maior emprego de efetivo, mas também e, principalmente, em ocorrências de menor relevo, cujos cuidados e atenção iniciais, traduzidos por um menor tempo resposta, podem significar prevenção de grandes incêndios, evitando ou minimizando perdas de vidas humanas, de patrimônio e, até, de recursos de enfrentamento. Vale dizer, o emprego de bombeiro civil e de bombeiro voluntário em tais ocorrências não se justifica apenas e tão-somente quando a vulnerabilidade a ser combatida seja numérica, mas também e, especialmente, quando o tempo se traduza na grande dificuldade a ser vencida.

\section{CONSIDERAÇÕES FINAIS}

Por tudo isso, conclui-se, que tanto o bombeiro civil quanto o bombeiro voluntário, carecem de regulamentação de suas atividades, de forma a serem fixados procedimentos ou protocolos de atendimento, áreas de atuação, limites espaciais, fiscalização, cadastramento, habilitação, instrução e orientação pelo Corpo de Bombeiros Militar e, principalmente, padronização de fardas e veículos. Ademais, não há que se falar em bombeiro voluntário enquanto pessoa jurídica, mas, apenas e tão-somente, como pessoa física vinculada ao CBMBA. Para tanto, faz-se urgente a edição de decreto estadual regulamentador da atividade de bombeiro voluntário e de decreto federal para regulamentar a profissão de bombeiro civil.

Até que se ultimem tais medidas legislativas, pode o CBMBA passar a cadastrar e a credenciar as empresas de bombeiro civil e os bombeiros voluntários, divulgando em sitio de internet aqueles que estejam em perfeito cumprimento das normas legais, especialmente, para possibilitar ao público em geral e ao potencial consumidor de tais serviços obterem parâmetro oficial de qualidade. Demais disso, deve o CBMBA promover representação ao Ministério Público da Bahia, cientificando-o das inúmeras irregularidades praticadas por bombeiros civis e voluntários no Estado da Bahia para fins de 
responsabilização cível, penal e ajustamento de conduta de pessoas e empresas, especialmente no que se refere ao uso indevido de uniformes, viaturas e prédios com forte similitude com os militares.

Destarte, tanto o bombeiro civil quanto o bombeiro voluntário nasceram como uma fonte de prestação de importante serviço que, a despeito de privado, tem o potencial de consubstanciar valorosa atenção às pessoas e ao patrimônio, ante a possibilidade de capilarização na maioria das edificações e espaços públicos e privados. Na prática, no entanto, devido à competitividade do mercado de prestação de serviços, as empresas disputam o espaço público como arena de demonstração de suas qualidades corporativas, usurpando funções públicas e vilipendiando marcas institucionais, como uniformes, quartéis e viaturas.

Esta realidade desafia o escalão superior da Corporação à reversão de quadro. São urgentes fazer bombeiro civil atuar preventivamente e em princípios de incêndio, dentro do espaço territorial que the compete e, bombeiro voluntário somar braços com os bombeiros militares em ocorrências que demandam quantidades gigantescas de profissionais, como incêndios florestais, deslizamento de encostas, inundações, alagamentos, acidentes com múltiplas vítimas, grandes desastres etc., sobretudo no interior do Estado onde efetivo é um dos principais problemas, principalmente no cumprimento das missões, quer de defesa civil quer ordinárias, como salvamento e combate a incêndio, em áreas distantes das sedes dos grupamentos de bombeiros militares.

Atividades como a sistemática promoção de campanhas sociais de divulgação da imprescindibilidade para a sociedade dos chamados soldados do fogo e uma atuação presencial em assessoria parlamentar nas três esferas de poder, federal, estadual e municipal, darão conta de gestão embrionária para enfrentamento de ameaças que possam vir a suprimir ou a reduzir o âmbito de atuação do corpo de bombeiros militar, vez que o enfrentamento meramente jurídico não se mostra eficaz frente aos atuais embates que movimentam a 
legislação de acordo com conveniências e contingências econômicas, sociais e políticas.

São 417 municípios no Estado da Bahia e, certamente, o poder público não poderá prescindir de profissionais tecnicamente capazes de prevenir e proteger a população a um custo infinitamente menor que o demandado para contratação de bombeiros militares. Daí o potencial estratégico e o desafio ao escalão superior: lançar mão dessa força de trabalho, mediante convênios e parcerias, sem perder a identidade e a essencialidade do CBMBA.

\section{REFERÊNCIAS}

BAHIA. Constituição do Estado da Bahia de 1989. 1989. Disponível em: http:// http://www.legislabahia.ba.gov.br/documentos/constituicao-do-estado-dabahia-de-05-de-outubro-de-1989 /. Acesso em: 27 jul. 2020.

BAHIA. Decreto oㅜ 16.302, de 27 de agosto de 2015. Regulamenta a Lei n.o 12.929, de 27 de dezembro de 2013, que dispõe sobre a Segurança contra Incêndio e Pânico e dá outras providências. Disponível em: http://www.legislabahia.ba.gov.br/documentos/decreto-no-16302-de-27-deagosto-de-2015. Acesso em: 27 jul.2020.

BAHIA. Histórico. O Combate aos Incêndios na Bahia durante o Império. A Criação do Corpo de Bombeiros Militar da Bahia. Disponível em: http://www.cbm.ba.gov.br/historico. Acesso em: 27 jul. 2020.

BAHIA. Instrução Técnica $n^{\circ}$ 17/2016. Brigada de Incêndio. Atualizada pela Portaria ${ }^{\circ} 057$ CG - CBMBA/17, de 28 de setembro de 2017. Disponível em: http://www.cbm.ba.gov.br/sites/defaultffiles/documentos/2018-10/it_17.2016__brigada_de_incendio.pdf. Acesso em 27 jul. 2020.

BAHIA. Lei no 7.990 de 27 de dezembro de 2001. Dispõe sobre o Estatuto dos Policiais Militares do Estado da Bahia e dá outras providências. Disponível em: http://www.legislabahia.ba.gov.br/documentos/lei-no-7990-de27-de-dezembro-de-2001. Acesso em: 27 jul. 2020.

BAHIA. Lei no 12.929, de 27 de dezembro de 2013. Dispõe sobre a Segurança Contra Incêndio e Pânico nas edificações e áreas de risco no Estado da Bahia. Disponível em: 
http://www.legislabahia.ba.gov.br/documentos/lei-no-12929-de-27-dedezembro-de-2013. Acesso em: 27 jul. 15.

BAHIA. Lei no 13.202 de 9 de dezembro de 2014. Institui a Organização Básica do Corpo de Bombeiros Militar da Bahia e dá outras providências. Disponível em: http://www.legislabahia.ba.gov.br/documentos/lei-no-13202-de09-de-dezembro-de-2014. Acesso em: 27 jul. 2020.

BAHIA. Corpo de Bombeiros Militar da Bahia. Operação Bahia sem Fogo. Histórico de Incêndios Florestais 2015 - Municípios Afetados $n^{\circ}$ 07/12. Lençóis, BA: $11^{\circ}$ GBM. dez. 2015.

BAHIA. Corpo de Bombeiros Militar da Bahia. Ofício n ${ }^{\circ} 069$ - SUBCMD/16. Lençóis, BA: 11ํㅡB. 29 mar. 2016.

BRASIL. Constituição da República Federativa do Brasil de 1988.

Disponível em:

http://www.planalto.gov.br/ccivil_03/constituicao/constituicaocompilado.htm. Acesso em: 27 jul. 2020.

BRASIL. Decreto-Lei no 2.848, de 7 de dezembro de 1940. Código Penal. Disponível em: http://www.planalto.gov.br/ccivil_03/decreto-

lei/Del2848compilado.htm. Acesso em: 27 jul.2020.

BRASIL. Decreto-Lei oㅜ 1.001, de 21 de outubro de 1969. Código Penal Militar. Disponível em: http://www.planalto.gov.br/ccivil_03/decretolei/Del1001.htm. Acesso em: 27 jul. 2020.

BRASIL. Decreto-Lei no 3.688, de 3 de outubro de 1941. Lei de Contravenções Penais. Disponível em:

http://www.planalto.gov.br/ccivil_03/decreto-lei/Del3688.htm. Acesso em: 27 jul. 2020.

BRASIL. Lei oㅜ 9.279, de 14 de maio de 1996. Regula direitos e obrigações relativos à propriedade industrial. Disponível em:

http://www.planalto.gov.br/ccivil_03/Leis/L9279.htm. Acesso em: 27 jul. 2020.

BRASIL. Lei no 9.608, de 18 de fevereiro de 1998. Dispõe sobre serviço voluntário e dá outras providências. Disponível em: http://www.planalto.gov.br/ccivil_03/leis/L9608.htm. Acesso em: 27 jul. 2020.

BRASIL. Lei no 11.901, de 12 de janeiro de 2009. Dispõe sobre a profissão de Bombeiro Civil e dá outras providências. Disponível em: http://www.planalto.gov.br/ccivil_03/_Ato2007-2010/2009/Lei/L11901.htm. Acesso em: 27 jul. 2020. 
BRASIL. Lei $n^{0} 12.608$, de 10 de abril de 2012. Institui a Política Nacional de Proteção e Defesa Civil - PNPDEC; dispõe sobre o Sistema Nacional de Proteção e Defesa Civil - SINPDEC e o Conselho Nacional de Proteção e Defesa Civil - CONPDEC; autoriza a criação de sistema de informações e monitoramento de desastres e dá outras providências. Disponível em: http://www.planalto.gov.br/ccivil_03/_ato2011-2014/2012/lei/L12608.htm. Acesso em: 30 jul. 2020.

MENEZES, Ebenezer Takuno de; SANTOS, Thais Helena dos. Verbete voluntariado. Dicionário Interativo da Educação Brasileira - Educabrasil. São Paulo: Midiamix, 2001. Disponível em:

https://www.educabrasil.com.br/voluntariado/. Acesso em: 27 de jul. 2020. 